\title{
Polycyclic Aromatic Hydrocarbons Degradation Techniques: A Review
}

\author{
Luke N. Ukiwe ${ }^{1}$, Ubaezue U. Egereonu ${ }^{1}$, Pascal C. Njoku ${ }^{1}$, Christopher I. A. Nwoko ${ }^{1} \&$ Jude I. Allinor ${ }^{1}$ \\ ${ }^{1}$ Department of Chemistry, Federal University of Technology, Owerri, Nigeria \\ Correspondence: Luke N. Ukiwe, Department of Chemistry, Federal University of Technology, P.M.B. 1526, \\ Owerri, Nigeria. Tel: 234-806-419-2946. E-mail: luggil2002@yahoo.com
}

Received: July 16, 2013 Accepted: September 3, 2013 Online Published: September 17, 2013

doi:10.5539/ijc.v5n4p43 URL: http://dx.doi.org/10.5539/ijc.v5n4p43

\begin{abstract}
The demand for processed petroleum products and agricultural produce has exposed our environment to polycyclic aromatic hydrocarbons (PAHs) contamination. PAHs stick to solid sediments and are ubiquitous including soil, water and air. Their presence in these media creates problems because consuming products obtained from these sources could be deleterious to human health since several of these compounds (benz(a)anthracene, benzo(a)pyrene, chrysene etc) have been implicated in causing tumors in animals and cancer in humans. The present review describes several remediation techniques which are efficient and cost effective in removing PAHs from the environment. Some of these conventional clean-up methods are not only environmental friendly; they also present a novel approach in reducing the ability of PAHs to cause prospective risk to humans and the ecosystem.
\end{abstract}

Keywords: atmosphere, contaminants, environment, hydrophobic, pyrene, pollutants, organics

\section{Introduction}

Polycyclic aromatic hydrocarbons (PAHs) are potent environmental pollutants that comprise fused aromatic rings. They are found almost everywhere in the environment and are typically formed during incomplete burning of organic materials such as wood, coal, oil, gasoline etc. PAHs are also found in crude oil, coal tar and asphalt (Fetzer, 2000). The presence of PAHs in the environment is related to human activities within the environment. Large concentrations of PAHs are expected to be present in urban areas and in areas where bush burning for agricultural farming is commonly practiced as well as in petroleum exploration and refining operations (Fetzer, 2000). Naphthalene is the simplest polycyclic aromatic hydrocarbon (PAH). PAHs are of great concern to humans since as pollutant, some have been identified as carcinogenic, mutagenic and teratogenic (Larsson, Sahlberg, Eriksson, \& Busk, 1993). In the environment, PAHs are primarily found in soil, sediment and oily substrates. Their concentration in water or air is relatively small compared to soil. Natural crude oil and coal deposits contain significant amount of PAHs arising from chemical conversion of natural products molecules such as steroids (Roy, 1995). PAHs are also formed by incomplete combustion of carbon containing fuels such as fat. Forest fires and agricultural bush burning account for the largest volume of PAHs from any natural source in the atmosphere. The actual amount of PAHs emitted from forest fires and agricultural bush burning vary with the type and nature of the fire as well as the intensity of the fire (Platt \& Mackie, 1980). Once exposed to the atmosphere, most of the pollutant do not degrade quickly and may thus reside in the environment for extended periods of time (Platt \& Mackie, 1980). During this period, winds may distribute the pollutant over a large area in a global manner (Platt \& Mackie, 1980).

PAHs' presence in fossil fuels such as coal and crude oil deposits occur due to low temperature combustion of organic material over a significant period of time. Since most oil deposits are trapped deep beneath layers of rock, there is little chance of the oil deposits emitting PAHs to the surface environment. However, some petroleum bodies such as tar-sand exist near the soil surface and are capable of contributing PAHs to both atmospheric and aquatic systems. Incomplete combustion at high temperature appears to be one of the major anthropogenic sources of environmental PAHs contamination. The production of PAHs during pyrolysis involves many sources which include pyrosynthesis and catalytic break down of petroleum products. PAHs compounds contain two to seven membered (fused) benzene rings. They are hydrophobic (they mix more easily with oil than water) compounds with aqueous solubility decreasing almost linearly with increase in molecular mass (Parish, Banks, \& Schwab, 
2009). The compounds may be classified as low molecular weights (LMW) or high molecular weights (HMW). LMW PAHs are those containing two or three benzene rings, while those with four or more benzene rings are called HMW PAHs. LMW PAHs are relatively water soluble, but those containing four or more rings are quite hydrophobic and insoluble (Cerniglia \& Heitkamp, 1989). However, the higher the molecular weight of a PAH, the more likely it is to absorb to soil organic matter. This tendency to strongly adsorb on particulate matter renders the HMW PAHs less available and thus less susceptible to remediation (Cerniglia \& Heitkamp, 1989). HMW PAHs have high resonance energies due to the dense clouds of pi-electrons surrounding the aromatic rings making them persistent in the environment and recalcitrant to degradation (Johnson, Wick, \& Harms, 2005). Another reason for the compounds to exhibit recalcitrant nature is their low aqueous solubility and high soil sorption (Parish, Banks, \& Schwab, 2009). PAHs are affected by several physical, chemical and biological processes which alter their fate and transport in the subsurface environment. The nature of the subsurface environment determines if the individual compound may remain as a non-aqueous phase liquid, metabolized by microorganisms, taken up by plants, be volatilized into the interstitial void spaces, or be sorb onto soil organic matter (Cerniglia \& Heitkamp, 1989). However, desorption from the organic matter is a critical step in the degradability of PAHs (Cerniglia \& Heitkamp, 1989).

A critical over-view of several degradation techniques has been presented in this review. These techniques include; chemical degradation, biodegradation, phytodegradation as well as combined degradation methods. Other developing degradation methods that has gained wide public acceptance include; solar ultraviolet radiation, direct photolysis and ultrasound frequency degradation. However, sonochemical degradation, photocatalytic degradation as well as current density enhanced degradation are novel approaches that have been tested successfully for the compound's removal.

\subsection{Determination of PAHs}

Many analytical techniques have been applied in the determination of PAHs and their metabolites in contaminated systems. Ter-Laak, Agbo, Barendregt, and Hermens (2006) examined the use of solid-phase extraction (SPE) in measuring freely dissolved concentrations of PAHs in soil pore water. Some researchers have suggested that solid-phase microextraction (SPME) with gas chromatographic/mass spectrometric (GC/MS) analysis can achieve detection limit as low as nanograms per litre of PAHs and alkyl PAHs in sediment pore water (Hawthorne, Grabanski, Miller, \& Kreitinge, 2005). In soil samples, high resolution gas chromatography-mass spectrometry (HRGC-MS) and liquid chromatography-fluorescence detection (LC-FD) have been applied successfully in measuring the final concentrations of PAHs (Berset, Ejem, Holzer, \& Lischer, 1999). It was revealed that HRGC-MS has a high linear range compared to LC-FD. Hence, under practical considerations, HRGC-MS was regarded as a superior analytical technique than LC-FD (Berset, Ejem, Holzer, \& Lischer, 1999). A recent study had noted that laser-induced fluorescence (LIF) spectroscopy is a mature technique for PAHs determination in terrestrial sediments (Grundl, Aldstadt, \& Harb, 2003). In a related study, SPME coupled with LIF was applied successfully in in-situ sampling in an effort to develop a simple field-portable method to determine total dissolved PAHs concentrations in sediment pore water (Hawthorne, St. Germain, \& Azzolina, 2008). It was evident that PAHs undergo a variety of processes resulting from chemical, biological or photochemical reactions. Hence, environmental conditions usually affect intermediate products of PAHs formed during degradation processes. A notable study by Dabroska, Kot-Wasik, and Namiesnik (2005) has revealed that different degradation pathways of PAHs require specialized analytical tools in their degradation studies. Jiang et al. (2007) also used GC-MS in analyzing sediment samples in a study aimed at characterizing the distribution of PAHs in sediment samples.

\section{PAHs Degradation Techniques}

\subsection{Chemical Degradation}

Determination of PAHs degradation in the environment is quite an onerous task. The occurrence of PAHs in anaerobic conditions depends on certain factors which include substrate interaction, $\mathrm{pH}$ and redox conditions (Chang, Shiung, \& Yuan, 2002). Stimulation of PAHs degradation rate under sulphate reducing conditions have been examined (Bach, Kim, Choi, \& Oh, 2005). PAHs in soil could be degraded through biotic processes. Oxidation reactions are viewed as the most effective in this regard, although some authors have suggested that photochemical reactions may also aid oxidative reaction processes (Kochany \& Maguire, 1994). It must be noted that most oxidation reactions in the environment are initiated by oxidants such as peroxides $\left(\mathrm{H}_{2} \mathrm{O}_{2}\right)$, ozone $\left(\mathrm{O}_{3}\right)$ and hydroxyl radicals generated by photochemical processes. The degradation pathways are such that the oxidation reaction involving hydroxyl radicals or $\mathrm{O}_{3}$ react with aromatic compounds such as PAHs at near diffusion-controlled rates by abstracting hydrogen atoms or by addition to double bonds (Haag \& Yao, 1992). Ozone may attack double bonds directly or it can form reactive hydroxyl radicals (which attack double bonds) by 
decomposing water (Legrini, Oliveros, \& Braun, 1993; Gurol \& Singer, 1982; Yao, Huang, \& Masten, 1998a, 1998b). The reaction proceeds with complex pathways producing numerous intermediates. However, the final reaction products include a mixture of ketones, quinones, aldehydes, phenols and carboxylic acids for both oxidants (Lee, Iso, \& Hosomi, 2001; Rivas, Beltran, \& Acedo, 2000; Reisen \& Arey, 2002; Koeber, Bayona, \& Niessner, 1997). Photochemical degradation of PAHs often involves the same oxidative species that are produced during the pure chemical oxidation of PAHs. Consequently, the reaction products include similar complex mixtures (Barbas, Sigman, \& Dabestani, 1996; David \& Boule, 1993; Mallakin, Dixon, \& Greenberg, 2000).

When PAHs undergo chemical reactions, they are transformed into other polyaromatic hydrocarbons (they do not lose their aromatic character). Their aromaticity is conserved since considerable amounts of energy are required to change an aromatic compound into a non-aromatic compound.

The localization energy concept has proven very effective in determining the positions of reaction molecules within the PAH structure. These positions could be determined by considering electron distribution over the PAH molecule. The localization energy isolates a pi-electron at the centre of a PAH molecule from the remaining pi-electron system (Dewar, 1952). The attacking species may be an electrophile or a radical. This attack leads to a degradation process of complete mineralization of the PAH molecule resulting in carbon dioxide $\left(\mathrm{CO}_{2}\right)$, water $\left(\mathrm{H}_{2} \mathrm{O}\right)$, and other inorganic and organic compounds (Barbas, Sigman, \& Dabestani, 1996; David \& Boule, 1993). If the chemical oxidant is added in insufficient quantity, the PAH could be metabolically transferred into dead-end products which are resistant to further degradation. This dead-end product could build-up in the environment and become a source for further contamination if no remedial process (especially the presence of microbe) is available for their further degradation (Freeman \& Harris, 1995). Ambrosoli, Petruzzelli, Minati, and Minati (2005) suggested that under denitrifying conditions, PAHs could be degraded through fermentative metabolism, while some studies have demonstrated that PAHs degradation in anaerobic environment is considered much slower than in aerobic environment (McNally, Mihelcic, \& Lucking, 1991). Fenton's reagent has been shown to have observed efficacy in degrading PAHs (Nam, Sweetman, \& Jones, 2009). Other chemicals used effectively to degrade PAHs include electron donors such as acetate, lactate and pyruvate (Bach, Kim, Choi, \& Oh, 2005). Under both aerobic and anaerobic conditions, degradation of PAHs has been observed to increase by physical/chemical pretreatment of contaminated soil using phosphorus (P) (Haritash \& Kaushik, 2009). Effects of carbon (C), nitrogen (N), and phosphorus (P) on PAHs degradation have also been investigated by several authors including (Ley, Bastiaens, Verstraete, \& Springael, 2005; Quan et al., 2009). Further studies have revealed that addition of $\mathrm{N}$ and $\mathrm{P}$ to soil can help to evaluate the response of phenanthrene degradation (Johnson \& Scow, 1999). Nitrate reduction has been the focus of so many researches (Mihelcic \& Luthy, 1988; Rockne \& Strand, 1998). Another study by Leduc, Samson and Al-Bashir (1992) had noted that acenaphthrene, fluorene and anthracene were capable of being degraded in denitrifying environment. Lovley, Woodward, and Chapelle (1994) have reported that ferric oxide reduction process has a limiting factor when applied in PAHs degradation. This limiting factor stems from the fact that ferric oxide is sparingly soluble in water. However, the study went further to note that chelating agents are added to subsurface environment to enhance solubility of ferric oxides and hence increase its bioavailability.

As already noted, the efficiency of PAHs chemical degradation is limited by their low aqueous solubility and vapor pressure (Luning \& Pritchard, 2002). Nonetheless, surfactants have been reported to contain properties that overcome problems related to PAHs low aqueous solubility (Boochan, Britz, \& Stanley, 1998). Surfactants enhance the solubility of hydrophobic compounds (Boochan, Britz, \& Stanley, 1998). Several studies have stressed the importance of surfactants to increase the solubility of PAHs by decreasing the interfacial surface tension between PAH and the soil/water interphase (Li \& Chen, 2009). In one study, the efficiency of surfactants in enhancing desorption of PAHs from contaminated soils relative to water was evaluated (Zhou \& Zhu, 2009). The study concluded that the efficiency of surfactant enhanced desorption for contaminated soils depended on the component characteristics of soil-surfactant-PAHs system and thus desorption efficiency show a strong dependence on the soil composition, surfactant structure, and PAH properties (Zhou \& Zhu, 2009). Addition of non-ionic surfactant as additives to soil has positive effect on PAHs degradation (Grimberg, String-fellow, \& Aitken, 1996; Volkering, Breure, Van Andel, \& Rulkens, 1995). However, some researchers have reported negative or negligible effects of adding surfactants to soil substrate (Ghosh, Yeom, \& Shi, 1995; Laha \& Luthy, 1992). Possible reason for this negativity includes; the competition for substrate utilization and toxicity of the surfactants towards PAHs-degrading bacteria in the soil matrix (Liu, Zhu, \& Shen, 2001). Hence, PAHs-degradation process involving surfactant utilization need to be optimized for each of the factors influencing degradation including, surfactant type and concentration, PAH specificity as well as presence of host 
bacteria (Jin, Juang, Jing, \& Ou, 2007).

\subsection{Biodegradation}

Biodegradation is one of the forms of bioremediation applied to treat soils, water or sediments contaminated with PAHs. It is the use of microorganisms to degrade or detoxify environmental pollutants (Bamforth \& Singleton, 2005). Biodegradation is also a clean-up method that presents the possibility to eliminate organic contaminants with the aid of natural biological activity available in the substrate (Zeyaullah et al., 2009). The microorganisms used for biodegradation should be indigenous to the contaminated area or site (Das \& Chandran, 2011). It is expected that the bacteria be able to degrade the contaminant by multiplying in population and then decline when the contaminant is finally degraded (Mougin, 2002). The products of complete mineralization of the pollutant by biodegradation process include; $\mathrm{CO}_{2}, \mathrm{H}_{2} \mathrm{O}$ and cell biomass (Gratia et al., 2006). The optimization of biodegradation process involves many factors among which are the existence of a microbial consortia capable of degrading the pollutant, the bioavailability of the contaminant to microbial attack and certain environmental factors (soil type, temperature, soil $\mathrm{pH}$, oxygen level of soil, electron acceptor agents, nutrient content of soil) contributing to microbial growth (Gratia et al., 2006).

Many researchers are of the opinion that certain bacteria isolates are capable of degrading PAHs. Of particular note are the studies carried out by Punapayak, Prasongsuk, and Messner (2009) and Abd-Elsalam, Hafez, and Hussain (2009). Punapayak, Prasongsuk, and Messner (2009), investigated the use of laccase enzyme produced from an isolate of the white rot fungus Genoderma lucidum. It was revealed that G. lucidum degrade anthracene completely with or without the addition of a redox mediator. However, Abd-Elsalam, Hafez, and Hussain (2009), concluded that Escherichia coli, Alcoligenes sp., and Thiobacter subterraneus were efficient isolates for degrading anthracene and phenanthrene. A number of studies have reported extensively on a variety of other bacterial species that have been isolated and noted to posses the ability to utilize PAHs as energy source (Cerniglia, 1992; Kiyohara, Nagao, \& Yana, 1982; Sahseverino, Applegate, King, \& Sayler, 1993; Zhao, Wu, \& Wang, 2009; Zhang et al., 2009; Ling et al., 2011; Zhao et al., 2008). Some microorganisms mainly from the genera Pseudomonas and Mycobacterium have been found capable of transforming and degrading PAHs under aerobic conditions (Mrozik, Piotrowska-Seget, \& Łabużek, 2008). It is also evident that anthracene could be completely mineralized by Sphingomonas, Nocardia, Beijerinckia, Paracoccus, and Rhodococcus with dihydriol as the initial oxygenated intermediate (Evans, Fernley, \& Griffiths, 1965; Dean-Ross, Moody, \& Freeman, 2001; Moody, Freeman, Doerge, \& Cerniglia, 2001; Teng et al., 2010). The ultimate goal of any remediation process should not be limited to removing contaminants from polluted substrates but should also include restoring the ability of the soil to function according to its potential (Epelde, Mijangos, Becenil, \& Garbisu, 2009). In this regard, the bioavailability of PAHs becomes a very important factor to consider. Bioavailability of PAHs in biodegradation is determined by certain complex interactions between biotic and abiotic factors. Biotic factors affecting bioavailability include; the metabolic ability of microorganisms to degrade PAHs as well as the ways in which the bacteria encourage PAHs accessibility. One way by which microbes encourage PAHs accessibility is by the production of biosurfactants. Biosurfactants are produced to increase the solubility of insoluble substrates or solubilized (emulsify) insoluble substrates in order to enhance their direct contact between microorganisms and contaminants (Mulligan, 2005). Evidence have been accumulating to suggest that certain microorganisms namely; Bacillus subtilis, Pseudomonas, Aeruginosa and Torulopsis bombicola could produce bioremediation surfactants such as surfactin, rhamolipid and sophorolipid capable of improving bioremediation by solubilizing PAHs into the aqueous medium and enhance their bioavailability for degradation (Cottin \& Merlin, 2007; Kuyukina et al., 2005).

\subsection{Phytodegradation}

This is a process whereby plants are used in-situ as well as their associated microorganisms to extract, sequester or detoxify pollutants from contaminated systems (Epuri \& Sorenson, 1997). Phytodegradation also referred to as phytotransformation is an important phytiremediation process which indicates the role of internal plant mechanisms and processes in removing contaminant from substrates (Newman \& Reynolds, 2004). Research has indicated that various grasses and leguminous plants are potential candidates for phytodegradation of organics (Adam \& Duncan, 1999). Some tropical plants have also been reported to show effective degradation tendency due to inherent properties such as deep fibrous root system and tolerance to high hydrocarbon and low nutrient availability (Dzantor, Chekol, \& Vough, 2000). Recently published data have revealed that the tall fescue grass (Festuca arundinacea) and switch grass (Pannicum virgatum) are capable of degrading about $38 \%$ of pyrene in 190 days (Chen, Banks, \& Schwab, 2003). Other studies involving pyrene degradation include that of Chouychai et al. (2009) and Cheema et al. (2009) who documented evidence showing plant enhanced phenanthrene and pyrene degradation in acidic soil as well as degradation of phenanthrene and pyrene in spiked soils by single and 
combined plants cultivation. These authors all agreed that the presence of vegetation such as corn (Zea mays), alfalfa (Medicago sativa) and rape seed (Brassica napus) significantly enhanced the adsorption of PAHs from contaminated soils. Moreover, $F$. arundinacea has been reported to show promising efficiency in promoting phytodegradation of PAHs in contaminated soils (Cheema et al., 2008). Meanwhile, it has been suggested that rice (Oryza sativa) is able to degrade PAHs successfully (Du et al., 2011). The effectiveness of phytodegradation has also been observed when the process was applied as a secondary treatment process for decontamination of PAHs composted soils (Parish, Banks, \& Schwab, 2004). However, in contrast to the study of Parish, Banks, and Schwab (2004), some studies have documented phytodegradation as a primary remediation technology and a final polishing step for treatment of soil contaminated with PAHs (Pradham, Conrad, Paterek \& Srivastava, 1998). Reduction of PAHs concentration was evident after six months of treatment with P. virgatum and little bluestem grass (Schizachyrium scoparium). In a related study, Campbell, Paquin, Awaya, and Li (2002) noted that using industrial hemp (Cannabis sativa) in treating PAHs contaminated soil, led to reduced concentrations of benzo(a)pyrene and chrysene. Recent advances in phytodegradation studies have come to light in the application of rye grass (Lolium multiflorum) and bermudagrass (Cynodon dactylon) in degrading alkylated two ring naphthalenes (White, Wolf, Thoma, \& Reynolds, 2006). In their contribution on distribution of PAHs in sub-cellular root tissue, Kang, Chen, Gao, and Zhang (2010) and Ward, Singh, and Van Hamme (2003) had revealed that using L. multiflorium, pyrene was most adsorped in the root of the plant than other PAHs. Previous studies from Simonich and Hites (1994), Bakker, Vorenhou, Sum, and Kolloffel (1999) and Gao and Zhu (2004) are of the opinion that the efficiency of plant uptake and metabolism of PAHs depended on the morphology of the plant system.

The efficiency of water hyacinth (Eichhornia crassipes) in degradation of organics has been investigated by Xia (2008). The plant is also reported to accumulate high levels of five and above rings PAHs as opposed to two and three rings compounds (Moustafa \& Shara, 2009). Wolverton (1975), showed that E. crassipes was able to adsorb organics and rapidly metabolize these to other components, while in a follow-up study, Wolverton \& McDonald (1976) had demonstrated that the plant can adsorb and metabolize phenols and other trace organics. According to Nesterenko, Kirzhner, Zimmels, and Armon (2012), E. crassipes devoid of rhizospheric bacteria reduced about $45 \%$ of naphthalene in waste water in 7 days. Some recognized studies have shown that $E$. crassipes could improve the quality of oil-refinery waste water by decreasing petroleum hydrocarbons by about $18 \%$ (Tang \& Lu, 1993). Nor (1994), shared the opinion that the plant has tremendous capability to adsorb phenolic compounds as well as heavy metals simultaneously. Recent findings have suggested that adsorption of hydrocarbons by E. crassipes is dominated by Van Der Waals forces (Lin \& Zheng, 2003). Hence, the plant has capability to adsorb other compounds such as inorganic nutrients and pesticides (Reddy, Agami, \& Tucker, 1989; Xia \& Ma, 2006; Rosas, Carbajal, \& Gómez, 1984; Ebel, Evangelou, \& Schaeffer, 2007; Ghabbour, Davies, Lam, \& Vozzella, 2004).

\subsection{Combined Degradation}

This is a novel degradation method whereby two or more degradation approaches are applied to remove PAHs from contaminated systems. It has the advantage over other degradation methods since it is regarded as efficient and cost effective, leaving behind no dead-end products capable of further contamination of the substrate after the clean-up exercise is over. Combined chemical pre-oxidation and bioremediation is a notable degradation approach investigated by Kulik, Goi, Trapido, and Tuhkanen (2005). Other studies in this regard include anaerobic digestion and ozonation (Bernal-Martínez, Carrière, Patureau, \& Delgenè, 2005), biodegradation and modified Fenton reagent (Nam, Rodriguez, \& Kukor, 2001), biological, chemical and electrochemical treatment (Zheng, Blais, \& Mercier, 2007) as well as Fenton reagent versus ozonation (Goi \& Trapido, 2004). A growing body of data have been reporting on the use of combined vegetation establishment with chemicals in degradation of PAHs (White, Wolf, Thoma, \& Reynolds, 2006; Pan et al., 2009; White, Wolf, Thoma, \& Reynolds, 2006) reported that a combination of L. arundinacum and L. multiflorum mixture with fertilizer successfully degraded two rings PAHs such as naphthalene. In a separate study, Pan et al. (2009) had observed that B. napus degraded PAHs in humic acid environment. Successes in combined degradation of PAHs have been documented using pressure assisted ozonation (Hong, Nakra, Jimmy, \& Hayes, 2008) and integrated treatment using soil washing, ozonation, and biological treatment of substrate (Haapea \& Tuhkanen, 2006). Oxidation using ozone in the presence of sand was examined by Choi et al. (2001), while combined treatment using sequence extraction with surfactant-electrochemical degradation was successfully employed by Alcántara, Gómez, Pazos, and Sanromán (2008). Recent developments in the study of combined degradation method have come to light following reports published by Bernal-Martínez, Patureau, Delgenè, and Carrière (2009) and Bernal-Martínez, Carrière, Patureau, and Delgenè (2007) in the use of anaerobic digestion with recirculation of ozonated digested sludge and 
anaerobic digestion using ozone pre-treatment. Combined chemical and phytodegradation using inorganic nutrients such as $\mathrm{NaNO}_{3}, \mathrm{Na}_{2} \mathrm{SO}_{4}$ and $\mathrm{Na}_{3} \mathrm{PO}_{4}$ each with E. crassipes is an evolving innovative approach that is beginning to gain wide public approval. Ukiwe, Egereonu, Njoku, and Nwoko (2013) had documented evidence showing that a combination of each of the above mentioned inorganic nutrients together with E. crassipes is capable of degrading about $95 \%$ of PAHs in soil leachate, while the plant uses same nutrients as energy source leaving behind no by products.

\subsection{Other Established Degradation Techniques}

Solar ultraviolet radiation has been shown to degrade and alter the quantity of organic pollutants such as PAHs (Bertilsson \& Widerfalk, 2002). Photochemical degradation of anthracene and phenanthrene was noted to be possible under the influence of humic acid (Bertilsson \& Widerfalk, 2002). Direct photolysis of PAHs has also been observed under simulated solar radiation with pyrene degrading at a faster rate than phenanthrene and naphthalene (Jacobs, Weavers, \& Chin, 2008). Similarly, ultra sound frequencies have been revealed to generate complete degradation of PAHs under operating conditions of $40{ }^{\circ} \mathrm{C}$ and applied current of $150 \mathrm{~W}$ (Psillakis, Goula, Kalogerakis, \& Mantzavinos, 2004). Wheat and Tumeo (1997) reported on the effectiveness of using sonochemical method to degrade phenanthrene and biphenyls in aerated aqueous solutions in the presence of $\mathrm{Fe}^{3+}$ ions. Further studies by Wang, Chen, and Yao (2003) and Manariotis, Karapanagioti, and Chrysikopoulo (2011) investigated sonochemical degradation of PAHs using high frequency ultrasound. Published data by Wang, Chen, and Yao (2003) and Manariotis, Karapanagioti, and Chrysikopoulo (2011) noted that the presence of chlorinated solvent during sonication resulted in the formation of solvent radicals which react with PAHs leading to the build-up of chloro-PAHs by-products which are degraded forms of the PAHs compound. Gordon and Cain (2003) documented observations supporting the already held belief that titanium film annular photocatalytic reactors are able to degrade PAHs in dilute water streams. Nevertheless, in their separate contribution, Alshawabkeh and Sarahney (2005) examined the effect of current density on enhanced transformation of naphthalene and concluded that almost $88 \%$ of the compound was degraded after $8 \mathrm{~h}$ when the current density was increased from 13-18.2 $\mathrm{mAL}^{-1}$, making this degradation approach one of the ideal novel processes of PAHs decontamination.

\section{Conclusion}

Removing PAHs from the environment is a very difficult task. Hence it is important to have a thorough understanding of the mechanism of the various degradation processes. The present study thus note that in-as-much-as each of these protocols in their merit are effective in depolluting PAHs from contaminated waste streams, the combined chemical and phytodegradation approach appears to be the most efficient and cost effective environmental friendly method to decontaminate PAHs from substrates. Firstly, it is a green degradation method that is mindful of the environment and secondly, no dead-end products are produced to initiate further contamination of the environment.

\section{References}

Abd-Elsalam, H., Hafez, E. F., Hussain, A., Ali, A. G., \& El-hanafy, A. A. (2009). Isolation and Identification of three-rings polyaromation hydrocarbons (anthracene and phenanthrene) degrading bacteria. American-Eurasian Journal of Agriculture and Environmental Science, 5, 31-38.

Adam, G., \& Duncan, H. (1999). Effect of diesel fuel on growth of selected plant species. Environmental Geochemistry and Health, 21, 353-357. http://dx.doi.org/10.1023/A:1006744603461

Alcántara, M. T., Gómez, J., Pazos, M., \& Sanromán, M. A. (2008). Combined treatment of PAHs contaminated soils using the sequence extraction with surfactant-electrochemical degradation. Chemosphere, 70, 1438-1444. http://dx.doi.org/10.1016/j.chemosphere.2007.08.070

Alshawabkeh, A. N., \& Sarahney, H. (2005). Effect of current density on enhanced transformation of naphthalene. Environmental Science and Technology, 39, 5837-5843. http://dx.doi.org/10.1021/es049645f

Ambrosoli, R., Petruzzelli, L., Minati, J. R., \& Minati, J. L. (2005). Selected PAHs concentration changes under nitrate and sulphate reducing conditions. Chemosphere, 60, 1231-1236. http://dx.doi.org/10.1016/j.chemosphere.2005.02.030

Bach, Q. D., Kim, S. J., Choi, S. C., \& Oh, Y. S. (2005). Enhancing the intrinsic bioremediation of PAHs contaminated anoxic estuarine sediments with biostimulating agents. Journal of Microbiology, 43, 319-324.

Bakker, M. I., Vorenhout, M., Sum, D., \& Kollôffel, C. D. (1999). Dry deposition of atmospheric polycyclic aromatic hydrocarbons in three plantago species. Environmental Toxicology and Chemistry, 18, 2289-2294. 
http://dx.doi.org/10.1002/etc.5620181025

Bamforth, S. M., \& Singleton, I. (2005). Bioremediation of polycyclic aromatic hydrocarbons: current knowledge and future directions. Journal of Chemical Technology and Biotechnology, 80, 723-736. http://dx.doi.org/10.1002/jctb.1276

Barbas, J. T., Sigman, M. E., \& Dabestani, R. (1996). Photochemcial oxidation of phenanthrene sorbed on silica gel. Environmental Science and Technology, 30, 1776-1780. http://dx.doi.org/10.1021/es950769p

Bernal-Martínez, A., Carrière, H., Patureau, D., \& Delgenè, J. P. (2005). Combining anaerobic digestion and ozonation to remove PAH from urban sludge. Process Biochemistry, 40, 3244-3250. http://dx.doi.org/10.1016/j.procbio.2005.03.028

Bernal-Martínez, A., Carrière, H., Patureau, D., \& Delgenè, J. P. (2007). Ozone pre-treatment as improver of PAH removal during anaerobic digestion of urban sludge. Chemosphere, 68, 1013-1019. http://dx.doi.org/10.1016/j.chemosphere.2007.02.019

Bernal-Martínez, A., Patureau, D., Delgenè, J. P., \& Carrière, H. (2009). Removal of polycyclic aromatic hydrocarbons $(\mathrm{PAH})$ during anaerobic digestion with recirculation of ozonated digested sludge. Journal of Hazardous Materials, 162, 1145-1150. http://dx.doi.org/10.1016/j.jhazmat.2008.05.163

Berset, J. D., Ejem, M., Holzer, R., \& Lischer, P. (1999). Comparison of different drying, extraction and detection techniques for the determination of priority polycyclic aromatic hydrocarbons in background contaminated soil samples. Analytical Chimica Acta, 383, 263-275. http://dx.doi.org/10.1016/S0003-2670(98)00817-4

Bertilsson, S., \& Widerfalk, A. (2002). Photochemical degradation of PAHs in freshwaters and their impact on bacterial growth-influence of water chemistry. Hydrobiologia, 469, 23-32. http://dx.doi.org/10.1023/A:1015579628189

Boonchan, S., Britz, M. L., \& Stanley, G. A. (1998). Surfactant enhanced biodegradation of high molecular weight polycylic aromatic hydrocarbon by Stenotrophomonas maltophilia. Biotechnology and Bioengineering, 59 , 482-494. http://dx.doi.org/10.1002/(SICI)1097-0290(19980820)59:4<482::AID-BIT11>3.0.CO;2-C

Campbell, S., Paquin, D., Awaya, J. D., \& Li, Q. X. (2002). Remediation of benzo (a) pyrene and chrysene-contaminated soil with industrial hemp (Cannabis sativa). International Journal of Phytoremediation, 4, 157-168. http://dx.doi.org/10.1080/15226510208500080

Cerniglia, C. E. (1992). Biodegradation of polycyclic aromatic hydrocarbons. Biodegradation, 3, 351-368. http://dx.doi.org/10.1007/BF00129093

Cerniglia, C. E., \& Heitkamp, M. A. (1989). Microbial degradation of polycyclic aromatic hydrocarbon (PAH) in the aquatic environment (2nd ed., pp. 41-68). Boca Raton, USA: CRC Press.

Chang, B. V., Shiung, L. C., \& Yuan, S. Y. (2002). Anaerobic biodegradation of polycyclic aromatic hydrocarbons in soil. Chemosphere, 48, 717-724. http://dx.doi.org/10.1016/S0045-6535(02)00151-0

Cheema, S. A., Khan, M. I., Shen, C., Tang, X., Farooq, M., Chen, L., . . . Chen, Y. (2009). Degradation of phenanthrene and pyrene in spiked soils by single and combined plants cultivation. Journal of Hazardous Materials, 16, 207-211. http://dx.doi.org/101016/j.jhazmat.2009.12.044

Cheema, S. A., Khan, M. T., Tang, X., Zhang, C., Shen, C., Malik, Z., . . Chen, Y. (2008). Enhancement of phenanthrene and pyrene degradation in rhizosphere of tall fescue (Festica arundinacea). Journal of Hazardous Materials, 9, 191-195. http://dx.doi.org/10.1016/j.jhazmat.2008.12.027

Chen, Y. C., Banks, M. K., \& Schwab, A. P. (2003). Pyrene degradation in the rhizosphere of tall fescue (Festuca arundinacea) and switchgrass (Panicum Virgatum). Environmental Science and Technology, 37, 5778-5782. http://dx.doi.org/10.1021/es030400x

Choi, H., Kim, Y. Y., Lim, H., Cho, J., Kang, J. W., \& Kim, K. S. (2001). Oxidation of polycyclic aromatic hydrocarbons by ozone in the presence of sand. Water Science and Technology, 43, 349-356.

Chouychai, W., Thongkukiatkul, A., Upatham, S., Lee, H., Pokethitiyook, P., \& Kruatrachue, M. (2009). Plant-enhanced phenanthrene and pyrene biodegradation in acidic soil. Journal of Environmental Biology, 30, 139-144.

Cottin, N. C., \& Merlin, G. (2007). Study of pyrene biodegradation capacity in two types of solid media. Science 
of the Total Environmental, 380, 116-123. http://dx.doi.org/10.1016/j.scitotenv.2007.03.016

Dabroska, D., Kot-Wasik, A., \& Namiesnik, J. (2005). Pathways and analytical tools in degradation studies of organic pollutants. Critical Reviews in Analytical Chemistry, 35, 155-176. http://dx.doi.org/101080/10408340500207565

Das, N., \& Chandran, P. (2011). Microbial degradation of petroleum hydrocarbon contaminants: An overview. Biotechnology Research International, 810-824. http://dx.doi.org/10.4061/2011/941810

David, B., \& Boule, P. (1993). Phototransformation of hydrophobic pollutants in aqueous medium. 1. PAHs adsorbed on silica. Chemosphere, 26, 1617-1630. http://dx.doi.org/10.1016/0045-6535(93)90107-G

Dean-Ross, D., Moody, J. D., Freeman, J. P., Doerge, D. R., \& Cerniglia, C. E. (2001). Metabolism of anthracene by Rhodococcus species. FEMS Microbiology Letters, 204, 205-211. http://dx.doi.org/10.1016/S0378-1097(01)00404-9

Dewar, M. J. S. (1952). A molecular orbital theory of organic chemistry VI: Aromatic substitution and addition. Journal of American Chemical Society, 74, 3357-3363. http://dx.doi.org/10.1021/ja01133a043

Du, W., Sun, Y., Cao, L., Huang, J., Ji, R., Wang, X., Wu, J., Zhu, J., \& Guo, H. (2011). Environmental fate of phenanthrene in lysimeter planted with wheat and rice in rotation. Journal of Hazardous Materials, 188, 408-413. http://dx.doi.org/10.1016/j.jhazmat.2011.01.116

Dzantor, E., Chekol, T., \& Vough, L. (2000). Feasibility of using forage grasses and legumes for phytoremediation of organic pollutants. Journal of Environmental Science and Health, A35, 1661. http://dx.doi.org/10.1080/10934520009377061

Ebel, M., Evangelou, M. W. H., \& Schaeffer, A. (2007). Cyanide phytoremediation by water hyacinth (Eichhornia crassipes). Chemosphere, 66, 816-823. http://dx.doi.org/10.1016/j.chemosphere.2006.06.041

Epelde, L., Mijangos, I., Becenil, J. M., \& Garbisu, C. (2009). Soil microbial community as bio-indicator of the recovery of soil functioning derived from metal phytoextration with sorghum. Soil Biology \& biochemistry, 41, 1788-1794. http://dx.doi.org/10.1016/j.soilbio.2008.04.001

Epuri, V., \& Sorensen, D. (1997). Benzo(a) pyrene and Hexachlorobiphenyl Contaminated Soil: Phytoremediation Potential (6th ed., p. 15). Washinton DC: American Chemical Society Press.

Evans, W. C., Fernley, H. N., \& Griffiths, E. (1965). Oxidative metabolism of phenanthrene and anthracene by soil Pseudomonads. The ring fission mechanism. Biochemical Journal, 95, 819-825.

Fetzer, J. C. (2000). The Chemistry and Analysis of the Large Polycyclic Aromatic Hydrocarbon (2nd ed., pp. 27-29). New York: Wiley Publishers.

Freeman, H. M., \& Harris, E. F. (1995). Hazardous Waste Remediation: Innovative Treatment Technologies (3rd ed., p. 463). Pennsylvania, USA: Technomic Publishing Company.

Gao, Y. Z., \& Zhu, L. Z. (2004). Plant uptake, accumulation and translocation of phenanthrene and pyrene in soils. Chemosphere, 55, 1169-1178. http://dx.doi.org/10.1016/j.chemosphere.2004.01.037

Ghabbour, E. A., Davies, G., Lam, Y. Y., \& Vozzella, M. E. (2004). Metal binding by humic acids isolated from water hyacinth plants (Eichhornia crassipes; solm-laubach: Pontedericeae) in the Nile Delta, Egypt. Environmental Pollution, 131, 445-451. http://dx.doi.org/10.1016/j.envpol.2004.02.013

Ghosh, M. M., Yeom, J. T. M., Shi, Z., Cox, C. D., \& Robinson, K. G. (1995). Microbial Processes for Bioremediation (2nd ed., p. 261). Columbus, USA: Batelle Press.

Goi, A., \& Trapido, M. (2004). Degradation of polycyclic aromatic hydrocarbons in soil: the Fenton reagent versus ozonation. Environmental Technology, 25, 155-164. http://dx.doi.org/10.1080/09593330409355448

Gordon, A., \& Cain, M. (2003). A titania thin film annular photocatalytic reactor for the degradation of polycyclic aromatic hydrocarbons in dilute water streams. Journal of Hazardous Materials, 99, 203-219. http://dx.doi.org/10.1016/S0304-3894(03)00060-8

Gratia, E., Weekers, F., Margesin, R., D’Amico, S., Thonart, P., \& Feller, G. (2006). Selection of a cold-adopted bacterium for bioremediation of wastewater at low temperature. Extremophiles, 13, 763-768. http://dx.doi.org/10.1007/s00792-009-0264-0

Grimberg, S. J., String-fellow, W. T., \& Aitken, M. D. (1996). Quantifying the biodegradation of phenathrene by Pseudomonas stutzeri P16 in the presence of a non-ionic surfactant. Applied and Environmental Microbiology, 62, 2387-2392. 
Grundl, T. J., Aldstadt, J. H., Harb, J. G., St. Germain, R. W., \& Schweitzer, R. C. (2003). Demonstration of a method for the direct determination of polycyclic aromatic hydrocarbons in submerged sediments. Environmental Science and Technology, 37, 1189-1197. http://dx.doi.org/10.1021/es020940e

Gurol, M. D., \& Singer, P. C. (1982). Kinetics of ozone decomposition: A dynamic approach. Environmental Science and Technology, 16, 377-383. http://dx.doi.org/10.1021/es00101a003

Haag, W. R., \& Yao, C. C. D. (1992). Rate constants for reaction of hydroxyl radicals with several drinking water contaminants. Environmental Science Technology, 26, 1005-1013. http://dx.doi.org/10.1021/es00029a021

Haapea, P., \& Tuhkanen, T. (2006). Integrated treatment of PAH contaminated soil by soil washing, ozonation and biological treatment. Journal of Hazardous Materials, 136, 244-250. http://dx.doi.org/10.1016/j.jhazmat.2005.12.033

Haritash, A. K., \& Kaushik, C. P. (2009). Biodegradation aspects of polycyclic aromatic hydrocarbons (PAHs): A review. Journal of Hazardous materials, 169, 1-5. http://dx.doi.org/10.1016/j.jhazmat.2009.03.137

Hawthorne, S. B., Grabanski, C. B., Miller, D. J., \& Kreitinge, J. P. (2005). Solid-phase microextraction measurement of parent and alkyl polycyclic aromatic hydrocarbons in milliliter sediment pore water samples and determination of K (DOC) values. Environmental Science and Technology, 39, 2795-2803. http://dx.doi.org/10.1021/es0405171

Hawthorne, S. B., St. Germain, R. W., \& Azzolina, N. A. (2008). Laser-induced fluorescence coupled with solid-phase microextraction for in-situ determination of PAHs in sediment pore water. Environmental Science and Technology, 42, 8021-8026. http://dx.doi.org/10.1021/es8011673

Hong, P. K., Nakra, S., Jimmy, K. C. M., \& Hayes, D. F. (2008). Pressure-assisted ozonation of PCB and PAH $\begin{array}{llll}\text { contaminated } & \text { Shemosphere, } & 72, & 1757-1764 .\end{array}$ http://dx.doi.org/10.1016/j.chemosphere.2008.04.061

Jacobs, L. E., Weavers, L. K., \& Chin, Y. P. (2008). Direct and indirect photolysis of polycyclic aromatic hydrocarbons in nitrate rich surface water. Environmental Toxicology and Chemistry, 27, 1643-1651. http://dx.doi.org/10.1897/07-478.1

Jiang, B., Zheng, H. L., Huang, G. Q., Ding, H., Li, X. G., Suo, H. T., \& Li, R. (2007). Characterization and distribution of polycyclic aromatic hydrocarbons in sediments of Haihe River, Tianjin, China. Journal of Environmental Sciences, 19, 306-311. http://dx.doi.org/10.1016/S1001-0742(07)60050-3

Jin, D., Juang, X., Jing, X., \& Ou, Z. (2007). Effect of concentration, head group, and structure of surfactants on the degradation of phenanthrene. Journal of Hazardous Materials, 144, 215-221. http://dx.doi.org/10.1016/j.jhazmat.2006.10.012

Johnson, A. R., Wick, L. Y., \& Harms, H. (2005). Principles of microbial PAH degradation in soil. Environmental Pollution, 133, 71-84. http://dx.doi.org/10.1016/j.envpol.2004.04.015

Johnson, C. R., \& Scow, K. M. (1999). Effect of nitrogen and phosphorus addition on phenanthrene biodegradation in four soils. Biodegradation, 10, 43-50. http://dx.doi.org/10.1023/A:1008359606545

Kang, F., Chen, D., Gao, Y., \& Zhang, Y. (2010). Distribution of polycyclic aromatic hydrocarbons in subcelluar root tissue of ryegrass (Lolium multiflorum). BMC Plant Biology, 10, 1471-1477. http://dx.doi.org/10.1186/1471-2229-10-210

Kiyohara, H., Nagao, K., \& Yana, K. (1982). Rapid screen for bacterial degrading water insoluble, solid hydrocarbons on agar plates. Applied and Environmental Microbiology, 43, 454-457.

Kochany, J., \& Maguire, R. J. (1994). Abiotic transformations of polynuclear aromatic hydrocarbons and polynuclear aromatic nitrogen heterocycles in aquatic environments. Science Total Environment, 144, 17-31. http://dx.doi.org/10.1016/0048-9697(94)90424-3

Koeber, R., Bayona, J. M., \& Niessner, R. (1997). Analysis of ozonolysis product of benzo(a) pyrene with capillary Gas Chromatography, Mass Spectrometry and Liquid Chromatography/Mass Spectrometry. International Journal of Environmental Analytical Chemistry, 66, 313-325. http://dx.doi.org/10.1080/03067319708028372

Kulik, N., Goi, A., Trapido, M., \& Tuhkanen, T. (2005). Degradation of polycyclic aromatic hydrocarbons by combined chemical pre-oxidation and bioremediation in creosote contaminated soil. Journal of Environmental Management, 78, 382-391. http://dx.doi.org/10.1016/j/jenvman.2005.05.005 
Kuyukina, M. S., Ivshina, I. B., Makarov, S. O., Litvinenko, L. V., Cunningham, C. J., \& Philip, C. J. (2005). Effect of biosurfactants on crude oil desorption and mobilization in a soil system. Recent Advances in Bioremediation, 31, 155-161. http://dx.doi.org/10.1016/j.envint.2004.09.009

Laha, S., \& Luthy, R. G. (1992). Effects of non-ionic surfactants on the solubilization and mineralization of phenanthrene in soil-water systems. Biotechnology and Bioengineering, 40, 1367-1380. http://dx.doi.org/10.1002/bit.260401111

Larsson, B. K., Sahlberg, G. P., Eriksson, A. T., \& Busk, L. A. (1983). Polycyclic aromatic hydrocarbons in grilled food. Journal of Agriculture and Food Chemistry, 31, 867-873. http://dx.doi.org/10.1021/jf00118a049

Leduc, R., Samson, B., Al-Bashir, J. Al-Hawari, J., \& Cseh, T. (1992). Use of nitrate to stimulate the biodegradation of polycyclic aromatic hydrocarbons. Water Science and Technology, 26, 51-60.

Lee, B. D., Iso, M., \& Hosomi, M. (2001). Prediction of Fenton oxidation positions in polycyclic aromatic hydrocarbons by Frontier electron density. Chemosphere, 42, 431-435. http://dx.doi.org/10.1016/S0045-6535(00)00061-8

Legrini, O., Oliveros, E., \& Braun, A. M. (1993). Photochemical processes for water treatment. Chemical Reviews, 93, 671-698. http://dx.doi.org/10.1021/cr00018a003

Leys, N. M., Bastiaens, L., Verstraete, W., \& Springael, D. (2005). Influence of the carbon/nitrogen/phosphorus ratio on polycyclic aromatic hydrocarbons degradation by Mycobacterium and Sphingomonas in soil. Applied Microbiology and Technology, 66, 726-736. http://dx.doi.org/10.1007/s00253-004-1766-4

Li, J. L., \& Chen, B. H. (2009). Effects of non-ionic surfactants on biodegradation of phenanthrene by marine bacteria of Neptunomnas naphthovorans. Journal of Hazardous Materials, 162, 66-73. http://dx.doi.org/10.1016/j.jhazmat.2008.05.019

Lin, Z. X., \& Zheng, F. X. (2003). Study on adsorption process for nitrobenzene on water hyacinth root. Shanghai Environmental Sciences, 12, 703-709.

Ling, J., Zhang, G., Sun, H., Fan, Y., Ju, J., \& Zhang, C. (2011). Isolation and characterization of a novel pyrene-degrading Bacillus vallismortis Strain JY3A. Science of the Total Environment, 409, 1994-2000. http://dx.doi.org/10.1016/j.scitotenv.2011.02.020

Liu, Y., Zhu, L., \& Shen, X. (2001). Polycyclic aromatic hydrocarbons (PAHs) in indoor and outdoor air of Hangzhou, China. Environmental Science and Technology, 35, 840-844. http://dx.doi.org/10.1021/es001354t

Lovley, D. R., Woodward, J. C., Chapelle, F. H. (1994). Stimulated anoxic biodegradation of aromatic hydrocarbons using Fe (111) ligands. Nature, 370, 128-131. http://dx.doi.org/10.1038/370128a0

Luning, P. D., \& Pritchard, P. H. (2002). Solubilization of polycyclic aromatic hydrocarbons mixtures in micellular non-ionic surfactant solution. Water Research, 36, 3463-3472. http://dx.doi.org/10.1016/S0043-1354(02)00070-2

Mallakin, A., Dixon, D. G., \& Greenberg, B. M. (2000). Pathway of anthracene modification under simulated solar radiation. Chemosphere, 40, 1435-1441. http://dx.doi.org/10.1016/S0045-6535(99)00331-8

Manariotis, I. D., Karapanagioti, K. H., \& Chrysikopoulo, C. Y. (2011). Degradation of PAHs by high frequency ultrasound. Water Research, 45, 2587-2594. http://dx.doi.org/10.1016/j.watres.2011.02.009

McNally, D. L., Mihelcic, J. R., \& Lucking, D. R. (1991). Biodegradation of mixtures of polycyclic aromatic hydrocarbons under aerobic and nitrate reducing conditions. Chemosphere, 38, 1313-1321. http://dx.doi.org/10.1016/S0045-6535(98)00532-3

Mihelcic, J. R., \& Luthy, R. G. (1988). Degradation of polycyclic aromatic hydrocarbon compounds under various redox conditions in soil-water system. Applied Environmental Microbiology, 54, 1182-1187.

Moddy, J. D., Freeman, J. P., Doerge, D. R., \& Cerniglia, C. E. (2001). Degradation of Phenanthrene and anthracene by cell suspensions of Mycobacterium sp. Strain PYR-1. Applied and Environmental Microbiology, 67, 1476-1481. http://dx.doi.org/10.1128/AEM.67.4.1476-1483.2001

Mougin, C. (2002). Bioremediation and phytoremediation of industrial PAH-polluted soils. Biotechnology Letters, 24, 2139-2142. http://dx.doi.org/10..1080/10406630214286

Moustafa, Y. M., \& Shara, S. I. (2009). Studies of seasonal variations on polycuclear aromatic hydrocarbons 
along the Nile River, Egypt. Journal of Applied Science Research, 5, 2349-2356.

Mrozik, A., Piotrowska-Seget, Z., \& Łabużek, S. (2003). Bacterial degradation and bioremediation of polycyclic aromatic hydrocarbons. Polish Journal of Environmental Studies, 12, 15-25.

Mulligan, C. N. (2005). Environmental applications for biosurfactants. Environmental Pollution, 133, 183-198. http://dx.doi.org/10.1016/j.envpol.2004.06.009

Nam, J. J., Sweetman, A. J., \& Jones, K. C. (2009). Polynuclear aromatic hydrocarbons (PAHs) in global background soils. Journal of Environmental Monitoring, 11, 45-48. http://dx.doi.org/10.1039/b813841a

Nam, K., Rodriguez, W., \& Kukor, J. J. (2001). Enhanced degradation of polycyclic aromatic hydrocarbons by biodegradation combined with a modified Fenton reaction. Chemosphere, 45, 11-20. http://dx.doi.org/10.1016/S0045-6535(01)00051-0

Nesterenko, M. A., Kirzhner, F., Zimmels, Y., \& Armon, R. (2012). Eichhornia crassipes capability to remove naphthalene from waste water in the absence of bacteria. Chemosphere, 87, 1186-1191. http://dx.doi.org/10.1016/j.chemosphere.2012.01.060

Newman, L., \& Reynolds, C. (2004). Phytodegradation of organic compounds. Current Opinion in Biotechnology, 15, 225-230. http://dx.doi.org/10.1016/j.copbio.2004.04.006

Nor, Y. M. (1994). Phenol removal by Eichhornia crassipes in the presence of trace metals. Water Research, 28 , 1161-1166. http://dx.doi.org/10.1016/0043-1354(94)90203-8

Pan, F., Chen, W., Zhang, Y. Q., Ying, C. M., Liu, Y., \& Zheng, Q. F. (2009). Fate of polycyclic aromatic hydrocarbons by composting of municipal sewage sludge and rapeseed meal. Huan Jing Ke Xue, 30, 3718-3723.

Parrish, Z. D., Banks, M. K., \& Schwab, A. P. (2004). Effectiveness of phytoremediation as a secondary treatment for polycyclic aromatic hydrocarbons (PAHs) in composted soil. International Journal of Phytomediation, 6, 119-137. http://dx.doi.org/10.1080/16226510490454803

Platt, M. M., \& Mackie, P. R. (1980). Distribution and fate of aliphatic and aromatic hydrocarbonis in Antarctic fauna and environment. Nature, 280, 576-578. http://dx.doi.org/10.1007/BF02414749

Pradham, S. P., Conrad, J. R., Paterek, J. R., \& Srivastava, V. J. (1998). Potential of phytoremediation for treatment of PAHs in soil at MGP sites. Journal of Soil Contamination, 7, 467-480. http://dx.doi.org/10.1080/10588339891334401

Psillakis, E., Goula, G., Kalogerakis, N., \& Mantzavinos, D. (2004). Degradation of polycyclic aromatic hydrocarbons in aqueous solutions by ultrasonic irradiation. Journal of Hazardous Materials, B108, 95-102. http://dx.doi.org/10.1016/j.jhazmat.2004.01.004

Punapayak, H., Prasongsuk, S., Messner, K., Danmek, K., \& Lotrakul, P. (2009). Polycyclic aromatic hydrocarbons (PAHs) degradation by laccase from a tropical white rot fungus (Ganoderma lucidum). African Journal of Biotechnology, 8, 5897-5900.

Quan, X., Tang, Q., He, M., Yang, Z., Lin, C., \& Guo, W. (2009). Biodegradation of polycyclic aromatic hydrocarbons in sediments from the Dalian River watershed, China. Journal of Environmental Science, 21, 865-871. http://dx.doi.org/10.1016/S1001-0742(08)62354-2

Reddy, K. R., Agami, M., \& Tucker, J. C. (1989). Influence of nitrogen supply rates on growth and nutrient storage by water hyacinth (Eichhornia crassipes) plants. Aquatic Botany, 36, 33-43. http://dx.doi.org/10.1016/0304-3770(89)90089-2

Reisen, F., \& Arey, J. (2002). Reactions of hydroxyl radicals and ozone with acenaphthrene and acenaphthylene. Environmental Science and Technology, 36, 4302-4311. http://dx.doi.org/10.1021/es025761b

Rivas, F. J. Beltran, F. J., \& Acedo, B. (2000). Chemical and photochemical degradation of acenaphthylene; $\begin{array}{lllll}\text { intermediate identification. Journal of Hazardous Materials, } & \text { 75, 89-98. }\end{array}$ http://dx.doi.org/10.1016/S0304-3894(00)00196-5

Rockne, K. J., \& Strand, S. (1998). Biodegradation of bicyclic and polycyclic aromatic hydrocarbons in anaerobic enrichments. Environmental Science and Technology, 22, 3962-3967. http://dx.doi.org/10.1021/es980368k

Rosas, I., Carbajal, M. E., Gómez, A. S., Belmont, R., \& Villalobos, P. R. (1984). Cytogenetic effects of cadmium accumulation on water hyacinth (Eichhornia crassipes). Environmental Research, 33, 386-395. 
http://dx.doi.org/10.1016/0013-9351(84)90037-9

Roy, G. M. (1995). Activated carbon applications in the food and pharmaceutical industries. Retrieved from $\mathrm{http} / / \mathrm{www} \cdot$ books.google.com

Sanseverino, J., Applegate, B. M., King, J. H., \& Sayler, G. S. (1993). Plasmid-mediated mineralization of naphthalene, phenanthrene, and anthracene. Applied and Environmental Microbiology, 59, 1931-1937.

Simonich, S. L., \& Hites, R. A. (1994). Vegetation atmosphere partitioning of polycyclic aromatic hydrocarbons. Environmental Science and Technology, 28, 939-943. http://dx.doi.org/10.1021/es00054a028

Tang, S. Y., \& Lu, X. W. (1993). The use of Eichhornia crassipes to cleanse oil refinery wastewater in China. Ecological Engineering, 2, 243-251. http://dx.doi.org/10.1016/0925-8574(93)90017-A

Teng, Y., Luo, Y., Sun, M., Liu, Z., Li, Z., \& Christie, P. (2010). Effect of bioaugmenattion by Paracoccus sp. strain HPD-2 on the soil microbial community and removal of polycyclic aromatic hydrocarbons from an

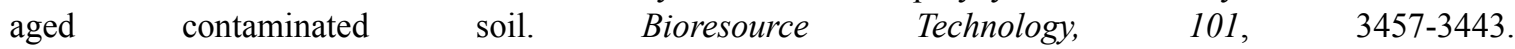
http://dx.doi.org/10.1016/j.biortech.2009.12.088

Ter-Laak, T. L., Agbo, S. O., Barendregt, A. \& Hermens, J. L. (2006). Freely dissolved concentrations of PAHs in soil pore water: measurements via solid-phase extraction and consequences for soil tests. Environmental Science and Technology, 40, 1307-1313. http://dx.doi.org/10.1021/es0514803

Ukiwe, L. N., Egereonu, U. U., Njoku, P. C., \& Nwoko, C. I. A. (2013). Combined chemical and water hyacinth (Eichhornia crassipes) treatment of PAHs contaminated soil. International Journal of Scientific and Engineering Research, 4, 1-12.

Volkering, F., Breure, A. M., Van Andel, J. G., \& Bulkens, W. H. (1995). Influence of non-ionic surfactants on bioavailability and biodegradation of polycyclic aromatic hydrocarbons. Applied and Environmental Microbiology, 61, 1699-1705.

Wang, X. K.., Chen, G. H., \& Yao, Z. Y. (2003). Sonochemical degradation of polychlorinated biphenyls in aqueous solution. Chinese Chemical Letters, 14, 205-208.

Ward, O. P., Singh, A., \& Van Hamme, J. (2003). Accelerated biodegradation of petroleum hydrocarbon waste. Journal of Industrial Microbiology and Biotechnology, 30, 260-270. http://dx.doi.org/10.1007/s10295-003-0042-4

Wheat, P. H., \& Tumeo, M. A. (1997). Solid-phase micro-extraction to monitor the sonochemical degradation of polycyclic aromatic hydrocarbons in water. Ultrasonics Sonochemistry, 4, 55-59. http://dx.doi.org/10.1016/S1350-4177(96)00017-X

White, P. M., Wolf, D. C., Thoma, G. J., \& Reynolds, C. M. (2006). Phytoremediaton of alkylated polycyclic aromatic hydrocarbons in a crude oil-contaminated soil. Water, Air and Soil Pollution, 169, 207-220. http://dx.doi.org/10.1007/s11270=006-2194-0

Wolverton, B. C. (1976). Water hyacinth for removal of phenols from polluted waters. Aquatic Botany, 2, 191-195. http://dx.doi.org/10.1016/0304-3770(76)90020-6

Wolverton, B. C., \& McDonald, R. C. (1976). Don’t waste waterweeds. New Scientist, 71, 318-320.

Xia, H. (2008). Enhanced disappearance of dicofol by water hyacinth in water. Environmental Technology, 29, 297-302. http://dx.doi.org/10.1080/09593330802099684

Xia, H., \& Ma, X. (2006). Phytoremediation of ethion by water hyacinth (Eichhornia crassipes) from water. Bioresource Technology, 97, 1050-1054. http://dx.doi.org/10.1016/j.biortech.2005.04.039

Yao, J. J., Huang, Z. H., \& Masten, S. J. (1998a). The ozonation of pyrene: Pathway and product identification. Water Research, 32, 3001-3012. http://dx.doi.org/10.1016/S0043-1354(98)00056-6

Yao, J. J., Huang, Z. H., \& Masten, S. J. (1998b). The ozonation of benz(a)anthracene: Pathway and product identification. Water Research, 32, 3235-3244. http://dx.doi.org/10.1016/S0043-1354(98)00094-3

Zeyaullah, M. D., Atif, M., Islam, B., Abdelkafe, A. S., Sultan, P., EI-Saady, M. A., \& Ali, A. (2009). Bioremediation: A tool for environmental cleaning. African Journal of Microbiology Research, 36, 310-314.

Zhang, G. Y., Ling, J. Y., Sun, H. B., Luo, J., Fan, Y. Y., \& Cui, Z. J. (2009). Isolation and characterization of a newly isolated polycyclic aromatic hydrocarbons degrading Janibacter anophelis strain JYII. Journal of Hazardous Materials, 172, 580-586. http://dx.doi.org/10.1016/j.hazmat.2009.07.037 
Zhao, H. P., Wang, L., Ren, J. R., Li, Z., Li, M., \& Gao, H. W. (2008). Isolation and characterization of phenanthrene-degrdading strains Sphingomonas spp. ZPI and Tistrella sp. ZP5. Journal of Hazardous Material, 152, 1293-3000. http://dx.doi.org/10.1016/j.hazmat.2007.08.008

Zhao, H. P., Wu, S., Wang, L., Zhao, X. T., \& Gao, H. W. (2009). Degradation of phenathrene by bacterial strain isolated from soil in oil refinery fields in Shanghai, China. Journal of Hazardous Materials, 164, 863-871. http://dx.doi.org/10.1016/j.hazmat.2008.08.098

Zheng, X. J., Blais, J. F., Mercier, G., Bergeron, M., \& Drogui, P. (2007). PAH removal from spiked municipal wastewater sewage sludge using biological, chemical and electrochemical treatments. Chemosphere, 68, 1143-1152. http://dx.doi.org/10.1016/j.chemosphere.2007.01.052

Zhou, W., \& Zhu, L. (2007). Efficiency of surfactant-enhanced desorption for contaminated soils depending on the component characteristics of soil-surfactant-PAHs system. Environmental Pollution, 147, 66-73. http://dx.doi.org/10.1016/j.envpol.2006.08.081

\section{Copyrights}

Copyright for this article is retained by the author(s), with first publication rights granted to the journal.

This is an open-access article distributed under the terms and conditions of the Creative Commons Attribution license (http://creativecommons.org/licenses/by/3.0/). 